\title{
Modelling Barcelona
}

\author{
Gary W. McDonogh \\ Bryn Mawr College, Philadelphia \\ gmcdonog@brynmawr.edu
}

\begin{abstract}
This panoramic and introductory text serves as a presentation to a book of the same title that will appear in the US market in the coming months. It is a historical approach that, after using a Braudelian approach to identify the location of Barcelona in its Mediterranean context, aims to show the various periods of abundance and crisis during its thousand-year history that have made it the global city that it is today and formed the layers that make up the city's modern urban palimpsest.

The periods discussed are: 1 . commercial and colonial expansion in the Mediterranean during the Middle Ages until the crisis in the fifteenth century, 2. the impact on the city of the dynastic union of Catalonia and Castile during the era of colonial expansion in America, 3. industrialization and urban growth, a period of social struggle during which the bourgeois city and national identity were created, 4. the other side of Barcelona during industrialization: social strife, conflict and urban opposition, 5 . the Barcelona of the Franco era and 6. the postmodern Barcelona: from the Olympics to the present day. Alongside this overview, the text offers a substantial bibliography ranging from ethnographic and bistorical studies to literary texts and other sources of social documentation.
\end{abstract}

Keywords: urban history, Mediterranean, palimpsest, architecture, social contexts, global city, beritage, urban model.

Resumen: Este texto panorámico, de carácter introductorio, sirve como presentación de un libro con el mismo título que aparecerá en el mercado norteamericano en los próximos meses. Se trata de una aproximación bistórica que, tras identificar en un estilo braudeliano la ubicación de la ciudad en su contexto mediterráneo, pretende destacar las buellas de su conformación como ciudad global a través de las diferentes fases de plenitud y crisis que se han sucedido a lo largo de mil años de bistoria, forjando las capas que configuran hoy el palimpsesto urbano barcelonés.

Las etapas que se narran son las siguientes: 1) la expansión comercial y colonial mediterránea durante la Edad Media hasta su crisis en el siglo XV, 2) los efectos en la ciudad de la vinculación dinástica de Cataluña con Castilla en la era de la expansión colonial americana, 3) la industrialización, etapa de crecimiento urbano, de luchas sociales y de conformación de la ciudad burguesa y de una identidad nacional, 4) la otra Barcelona de la industrialización: luchas sociales, conflicto y contestación urbana, 5) la Barcelona de la era franquista y 6) la Barcelona posmoderna, desde las Olimpiadas hasta la actualidad. Junto a esta visión panorámica, el texto ofrece una abundante selección bibliográfica que abarca desde estudios etnográficos e bistóricos hasta obras literarias y otras fuentes de documentación social.

Palabras clave: Historia urbana, Mediterráneo, palimpsesto, arquitectura, contextos sociales, ciudad global, patrimonio, modelo urbano. 
Barcelona in the 2lst century has come to occupy a singular albeit paradoxical position as a "global city." Barcelona clearly is not a megalopolis by global standards, with 1.7 million inhabitants in the city and perhaps twice that in the urbanized metropolitan area. Nor has it been the capital of a state since the Aragonese-Catalan Empire engaged its unification into what would become Spain, beginning in the fifteenth century. Although the city and its polity regained importance in the $19^{\text {th }}$ century as a mercantile, financial and industrial center, today Barcelona controls neither significant global production nor financing. And while the home of multiple universities, museums, monuments and memories, its cultural orbit remains circumscribed. Catalan, its national language, boasts only ten million speakers, geographically concentrated (the bilingual city also remains an important center for a wider Spanishspeaking world). Even its most emblematic architect, Antoni Gaudí (18521926), completed few major works away from the city, while his Barcelona masterwork, the Expiatory Temple of the Sagrada Familia, remains caught up in a controversial and internationally-funded completion.

These sometimes anomalous limitations prove important because Barcelona as a city, its people and its place on a world stage so consistently defy them. Since recapturing a global stage with the 1992 Olympics, Barcelona has become an intensely popular destination for tourists, conferences, urbanists, students and economic migrants. Local campaigns to maintain and to adapt heritage, dramatic ongoing urban transformations, debates over culture, democracy, peace and sustainability, transformational cuisine, dynamic athletics and ecological planning all have become issues of local creativity (and criticism) as well as global attention. These debates resonate with those of Barcelonins of previous generations who made the city a center for projects as diverse as maritime law, resurgent European nationalisms, anarchist bombings and modern art. Global Barcelona may have become an urban brand in the $21^{\text {st }}$ century, but it also embodies a complex and contradictory city, culture and people.

In recent years, citizens and scholars have sought to capture this peculiar creativity and visibility of Barcelona in terms of its role as an urban model. The 2004 Universal Forum of World Culture, for example, embodied a claim by local elites that Barcelona stood at the vanguard of global thinking around issues of peace, diversity and sustainability. The vainglorious publicity surrounding such 
an event (itself part of a tradition embracing the Olympics and many earlier events) met with skepticism among local intellectuals (Trallero 2004, Capel 2005, Delgado 2007) and everyday citizens (McDonogh 2011). Academic calls for a Barcelona model, by contrast, have underscored the position of Barcelona as a second city with a rich documentation of social and cultural transformations for a millennium within the palimpsest of the city (McNeill 1999, Rowe 2006, Amelang 2007, Oyón 2009). Others have highlighted the city's character as an urban laboratory reformulating contemporary issues of language (Woolard 1989, 2011; Conversi 1997, Ross 2007), urban form (Prince of Wales 1990, Marshall 2000, Busquets 2005, Capel 2005) and social issues ((Blanco 2009, McDonogh 2010, 2012, Erickson 2011). Underlying all these claims is the sense that Barcelona as a city and group of citizens speaks eloquently to urbanites worldwide. Moreover, while the model projected from Barcelona has overtones of triumphant success, analysts have read the city for multilayered process, debates, and questions about what citizens of Barcelona and urbanites worldwide value in a good city. This universal debate, however, remains rooted in struggles, internal and external, that have shaped this city and its citizens for centuries.

In undertaking an accessible one volume overview of Barcelona -something sorely lacking for classroom use and general reading since the already problematic Olympic paeans of Robert Hughes Barcelona (1992) and Manuel Vázquez Montalbán's Barcelonas (1992) - this text will emphasize an open sense of the city as a place and people within millennia of global flows and as a forum of questions as much as answers. ${ }^{1}$ While providing a clear framework of historical, political economic and social development of the city since the Middle Ages, my background and ongoing studies as an anthropologist and historian will help me to evoke multiple voices and alternative imaginations that have erupted into streets and academies there. And, while providing a foundation for American students who want to learn and talk about the city, this work should be a conduit as well for the intense academic study (and other debates) that have sought answers in Barcelona to a wider audience that does not read Catalan, Castilian, or French and important scholarly production in these languages.

1 Other less comparable texts of importance in English include McNeill 1999 and Busquets 2004. More critical texts continue to be produced in Spanish and Catalan, e.g. Carreras Verdaguer 1992, Capel 2005, etc. 
The text will be structured around four recurrent themes so as to provide a cogent overview of 2000 years of history and change; it includes roughly chronological but overlapping chapters with an emphasis on the city since the Industrial Revolution. The first theme is the physical form of the city (see Busquets 1992/2003; Bohigas, Buchanan and Magnago Lampugnani 1990; Michonneau 2001/2, Ingresso 2011, etc). Treasured by architectural historians and tourists alike, Barcelona's presence and absence from European history has made the city a unique palimpsest incorporating structures ranging from Roman ruins to post-modern starchitecture. The monuments, the walls, the boulevards, plazas and the marginal neighborhoods of the city constitute everyday experiences of history, struggle and possibility even as they have been restored and reinvented over time. While the theater of the city, in Lewis Mumford's sense, entails social construction over centuries, Barcelona has offered resplendent stagecraft between the mountains and the seacoast that will also allow visitors to associate history and social changes with the contemporary city.

A second primary theme will be the diversity of peoples in this Catalan city within a Castilian-dominated state. This appreciation of complexity begins from Barcelona's formation as a Mediterranean city and its history under the domination of Romans, Arabs, and Franks as while recognizing the historical presence and participation of Jews, Italian merchants, and New World "transnationals." Industrialization brought new waves of migrants into the city from rural areas and nearby Aragon and later from distant areas of Spain that contributed to crucial divisions of class and culture throughout the $20^{\text {th }}$ century (Candel 1969, 1985; McNeill 1999; Oyón 2009). Contemporary migrant populations from Africa, Asia and the rest of Europe have made Barcelona a newly cosmopolitan city within a multi-layered discussion of globalization and citizenship (McDonogh 1993, 2008; Delgado and Lozano 2007, Arriaga and Nicolas 2008; Nash, Benach and Tello 2008, Zontini 2010; McDonogh and Wong 2012). Moreover, the text will show how people come to grapple with and act on intersecting divisions of space, class, religion, gender, space and virtue across the changing city.

In the modern period, of course, this discussion will analyze the political, economic and human relations of Catalonia as a nation and Barcelona as its capital within a changing Spanish state. Here, themes such as the relation of 
Catalan as a language to a Castilian that embraced the dominant discourse of officials, the speech of local professionals and the accented language of poor southern Spanish immigrants will provide insights into contemporary society --and even the choices of Chinese or Senegalese immigrants choosing to incorporate Castilian, Catalan or both into their wider repertoires (Woolard 1989, 2011; Frekko 2011). Again, in its dynamic bilingualism over the past century, Barcelona represents a model response for global questions.

While the question of Castilian and Catalan power and presence in the city are deeply linked to the rise of the nation-state, such diversity also speaks to a third theme, globalization. As a city of migration in a terra de pas (land of travel), Barcelona has embodied multiple processes of globalization since its early colonization and conquest. Certainly, this includes economic change: the industrial revolution that transformed the city in the $18^{\text {th }}$ and $19^{\text {th }}$ century, for example, depended not only on immigrant workers but also on prior mercantile globalization including markets in the new world and technologies as well as competition from Northern Europe and North America (Schneidmann 1970, Vilar 1962, Thompson 1991, Oyón 2009). As the Barcelona bourgeoisie connected with styles from Paris and London, workers, in turn, found revolutionary models there and disseminated them in the Philippines and the New World (Seidman 1991, Anderson 2006). Long before the tragic global battles of the Spanish Civil War (1936-1939) or the contemporary relations of NATO, tourism, refugee migration and environmental policy that make the global local in Barcelona today, global flows constituted the city, its political economic foundations and its population in ways that nonetheless differentiate from the experience of most Northern metropoles as well as colonial/ postcolonial cities, even those that share the Mediterranean world (Seidman 1991, Ealham 2001, Oyón 2009). Again, Barcelona provides a laboratory for understanding and comparing alternative routes to the postmodern city (McNeill 1999, Bollens 2007, Tello et alii 2008).

Finally, as a student of culture, I want to introduce Barcelona in such a way as to incorporate institutions and agency, global spaces and trends as well as individual, even eccentric creativity and voice. While this text will present Barcelona in broad and accessible terms, it would be incomplete without myriad voices, whether the arguments of medieval Jews, the marvelous chivalrous worlds of Tirant lo Blanc (with commentary from Don Quijote), the $19^{\text {th }}$ 
century women's novels of Dolors Monserdà, the protest cries of anarchists and workers, the spirituality of Gaudí, the aesthetic vision of Picasso, Russinyol and Miró (Larson and Woods 2005, Robinson et al 2006) and even the indignats - young protestors - who recently took over streets and parks in a demand for opportunities in the $21^{\text {st }}$ century city that resonated from Cairo's Tahrir Square to Occupy Wall Street (Juris 2008). Any Barcelona model demands polyphony even within a cogently structured exposition.

These four themes, in turn will develop across seven major chapters (and an introduction that expands on the framing themes of this prospectus, framing the city and its people and setting up Barcelona as a model for global urbanism):

Introduction

A City of the Mediterranean, to roughly $1000 \mathrm{CE}$

Barcelona as Capital: Power in the Medieval and Renaissance City (roughly 1000-1500 CE)

City, Nation, State, Empire: The Great Transitions (1469-1700s)

Down with the Walls!!!: Industrialization, Nationalism and Identity in the $19^{\text {th }}$ and $20^{\text {th }}$ Century (roughly 1750-1939)

The Contested City, from the Factory to the Civil War (1830s-1939)

In and Out of Modernity: Barcelona During and After Franco (1936-1992)

Barcelona as Model for the $21^{\text {st }}$ Century (1992-

For discussion, I conclude with a preliminary summary of these chapters, their questions and some basic references (see attached bibliography).

\section{Chapter I Foundation: A City of the Mediterranean (pre- history to roughly $1000 \mathrm{CE}$ )}

This chapter will cover the physical setting, early history and socioeconomic context of the city within the framework of Mediterranean studies as developed by Braudel (1966), DiCastri and Mooney (1973) Horden and Purcell (2000), Abulafia (2000) and others - including counterpoints included in Harris (2005 especially Herzfeld 2005). As a subordinate colonial formation of Carthaginians and Romans, Barcelona lacked a significant protagonism in the classical and early medieval world until after the Franks reconquered it from a relatively brief Muslim occupation (See Bensch 1995, Kulikowsi 2004). Situating Barcelona within this larger framework allows the reader to begin to 
think about the growth and meaning of the city, however, in important ways framed by events such as the Roman conquest around 15BCE, the capture of the city by Muslims and its reconquest by Franks in 801 . The chapter, while laying an historical foundation, also links the city to the changing Mediterranean today (McDonogh 2011,2012) in a way that will emphasize the theme of the city as question as well as prototype. This will be shorter albeit broader than other chapters ( 5000 words)

\section{Chapter II Barcelona as Capital: the Medieval and Renaissance City (1000-1500)}

This chapter focuses on social and cultural issues of Barcelona within the Catalan principality and Aragonese empire in terms of the city and its people while covering the geopolitical changes of this period. The narrative must balance the peninsular struggles of Muslims and Christians known as the Reconquista and the peninsular and European dynamics of new kingdoms (Reilly 1992, 1993), including the Disputation of 1263 that staged critical arguments between Jews and Christians in a complex medieval society before peninsular society turned against the Jews in a wave of massacres that reached Barcelona in 1391 (Chazan 1992; Catlos 2004 Klein 2006). Locally, through the formation of urban political institutions and struggles, the activities of different economic actors (merchants, guilds, outsiders, church), the construction of a monumental city and the production of art and literature, global events intersect with growth and divisions that culminated in the merger of the lines of the Count of Barcelona and the Crown of Aragon in the $12^{\text {th }}$ century and the growth of a Mediterranean empire including Valencia, the Balearics and Naples before the scourge of the Black Death and the peasant (remensa) uprisings of the $15^{\text {th }}$ century. Along with many other historians and cultural scholars, this chapter humanizes this period through writers, polemicists and politicians as well as less heroic actors whose collaboration and disputes shaped an imperial capital that still constitutes the core of the city - and a sense of nation that shapes its citizenry (Dufourq 1966; Schneidman 1970 Bensch 1995, Chazan 1992, Kosto 2001, Klein 2006). The florescence of art, literature and architecture in the city also links to the $19^{\text {th }}$ century revitalization of Catalan language, culture and nationalism (6000 words) 


\section{Chapter III City, Nation, State, Empire: the Great Transitions (1400-1750)}

The question of when decline began within the Catalan empire and its capital and what, in fact, "decline" means has bedeviled scholars since the monumental work by J.H. Elliot (1963: see Amelang 1992, García Espuche 1998, 2005, Michonneau 2001/2). Starting with the events leading to the dynastic marriage of Ferdinand of Aragon and Catalonia in 1469 with Isabel of Castile and Leon and the "birth" of modern Spain, this chapter maps out major events of unification of the state, European politics and the emergence of a New World Empire that reshaped Barcelona, including Catalan exclusion from this new wealth and Catalonia's changing fortunes in the Mediterranean. It will pay special attention to the unsuccessful Catalan revolt of 1640-52 and its aftermath. This chapter also recognizes that scholars continue to find increasing complexity in the early modern city and its culture, ranging from the interpretation of themes of wider European discourses to ongoing local reform even at the moment later identified as cataclysmic defeat at the siege of Barcelona in 1714 (Fontana 1972, Molas Ribalta 1986, Amelang 1992, 2007; Kamen 1993, 2003; Michonneau 2001/2, Jacobson 2009). While sorting through multiple historical events and later interpretations remains the primary critical task of this chapter, cultural and architectural themes will actually demand less emphasis for the general reader. Yet this chapter will also tease out changes in urban life in this period (García Espuche and Guardia Bassols 1986; Amelang 1986, 2008; García Espuche 1995, 2005), as well as how key concepts of imagined and governed communities come into play in and around Barcelona (Maspons Anglasell 1907, Michonneau 2001/2002). Despite the crucial wider political scale of actions and statecraft that we must deal with, the book again reads Barcelona itself as an urban laboratory whose development is relevant for later and wider comparison (6000 words)

\section{Chapter IV Down with the Walls!!!: Industrialization, Nationalism and Identity in the $19^{\text {th }}$ and $20^{\text {th }}$ Century (mid $18^{\text {th }}$ century-1939)}

The rebirth of Barcelona from the ashes of siege and repression in the early $18^{\text {th }}$ century has been the mythic narrative of the struggle of the modern city 
to be great and has drawn in global scholars since Pierre Vilar (1962) and the magisterial Jaume Vicens Vives (1959, 1961), including global scholars who have challenged and elaborated on their work. It is important to follow - and respond to - this narrative in reading a triumphal city from the Napoleonic occupation $(1808-1813)$ through the $19^{\text {th }}$ century Reniaxença (linguistic and cultural renaissance) and the convergence of economic expansion and cultural growth that underpinned nationalism and an artistic, literary, musical and architectural florescence of the city into the $20^{\text {th }}$ century. Here, the urban expansion of the city built on the modernist geometries of the 1860 Cerdà plan provide a physical and temporal skeleton amid other markers of modernity like World Expositions of 1888 and 1929 (Cerdà 1867, Grau 1988; Grandas 1988). Here, I also break with chronological ordering by re-covering some of the same ground in Chapter V from a different vantage: while the struggles of elites and workers, Barcelonins and others need to nuance this great urban transformation, I think this organization will emphasize the way different citizens have fought to created quite different societies and even urban forms in Barcelona in the modern period. This is obviously a chapter that will draw on my own work on the bourgeoisie of the city and later critical developments in the study of economics, political power and urban change (McDonogh 1986; CarrerasVerdaguer 1992, Falgues et alii 2006; Jacobson 2009, etc). Critical readings of historical consciousness and power such as those raised by Epps (2004), Michonneau (2001/2), and Resina (2008) also will also anchor this in a more complex vision of the city as an area. This will be the longest chapter in the book, in part because of the artistic, architectural, literary and musical florescence of the period recently celebrated in major museum expositions worldwide (Robinson et al 2006, Sala 2008, etc.) (8000 words)

\section{Chapter V'The Contested City, from the Factory to the Civil War (1820s-1939)}

As factories and milltowns took shape in a modernizing Barcelona, protests arose against them. As a financial-industrial elite coalesced, it met opposition not only among competing power holders in the Spanish state and wider industrial world, but also among local citizens - workers, middle class critics, intellectuals, artists, housewives. A chapter on the contested city gives these voices their due as creators of a city even they remain unmarked in the 
boulevards, monuments and palaces of the turn of the century city. Beginning with the Luddite destruction of Spain's first steam-powered factory, El Vapor, in 1835, this chapter chronicles the emergence of anarchists, socialists as organized forces and the thoughts of men and women of the working class as well as the changing issues of the city evidenced in events such as the 1893 bombing of the Liceu opera house (McDonogh 1986) and the citywide repression of the Tragic Week of July 1909. The chapter ends with the issues of the second republic and civil war (1931-1939) as well as the global moment of the aborted 1936 Popular Olympics, scheduled to begin the day the Spanish Civil War broke out. Drawing on major ongoing works by Kaplan (1992), Balfour (1989), Seidman (1991), Kaplan (1992), Ealham (2001), Anderson (2006), Oyón (2009), and my own research on the portside barrio chino (McDonogh 1999, Maza 1999, see Davidson 2010), I will underscore the multiple Barcelonas that contested the modern period and their relevance for multiple contemporary issues from language to ecology (Masjuan Bracons 1992, Pi-Sunyer 2006). This chapter will also serve to guide readers to areas of contemporary debate that remain vivid in the city and beyond (6000 words) Chapter VI In and Out of Modernity: Barcelona During and After Franco (1936-1992)

Contemporary Barcelona was ruled for nearly four decades (1939-1976) by various avatars of a Spanish state unsympathetic to the cultural goals of the city if not to its economic values. By the time this book reaches readers, the city will have passed an equal period of separation from Franco - transitional, generally Catalan and socialist rule. In carefully reviewing decades together, we can trace common themes -the reshaping of the city, the meanings of division and globalization, the struggle for language and culture - that have made Barcelona both a vibrant city and a crucible for problems faced by many world metropoles -from urban redevelopment to migration, ecology and identity. As such, this chapter lays the foundations for current issues being questioned as much as answered in Barcelona, the themes that will constitute a contemporary concluding chapter on the basis of these historical and cultural analyses.

Although the chapter begins with the consolidation of the Francoist regime in 1939, it does not end with Franco's death in 1975 but moves onward through the transition to democracy that found its global capstone in the 1992 
Summer Olympiad. This division accepts the divergent experiences of those Franco years where industrial development was linked to traditional Catholic piety and modern architecture to international subversion - epitomized in the 1952 Eucharistic Congress in the city. Yet, it also looks to continuities and survivals that link the modern city with its earlier history, drawing together the voices and issues of the two previous chapters to show how the city, elites, workers and immigrants and creative life were transformed by war, the Francoist conquest of the city and Barcelona' subsequent development as a renewed immigrant industrial hub and then a center for European tourism that offered a new window to and from the continent in the 1950s and 1960s (Hansen 1977). From here, the chapter will examine through resistance that grew into the 1970s, amid Marxist and monastic venues, and the transition from Franco to a more democratic, localized (nationalist) regime for the city and the polity that brought socialists into control in 1979. The 1992 Olympics, hosted by a powerful socialist Mayor (Pascual Maragall,See Maragall 1968, Bohigas et al 1990, McNeill 1999) in counterpoint to a conservative Catalanist autonomous government and the grey eminence of a Francoist Catalan minister, Juan Antonio Samaranch critical to the selection process (Mauri and Uria 1998, McDonogh 1999, Hargreaves 2000). This chapter also follows themes of reform mentioned above including the politics of language and the reformation of the city as physical space as well as the economic transitions of the post-industrial period as well as those skeptical of this growth (King 2001, McNeil 1999, Delgado 2007, Keown 2011). (8000 words)

\section{Chapter VI Barcelona as Metropolitan Model for the $21^{\text {st }}$ Century}

Having posed Barcelona as a model city in the introduction, this final chapter situates the reader with regard to select contemporary debates where the city has become a referent for local change and global issues. While possibilities range from Barça football to the concoctions of new Catalan cuisines, three themes bring together the organizing principles of the text. Architecture and planning in the city have taken on new dimensions as they have converged with discussions of sustainability ranging from changing uses of the city to new technologies, epitomized in the Universal Forum of World Cultures of 
2004 (Trallero 2004, Capel 2005, Delgado 2007, Degen 2008, Ingresso 2011, McDonogh 2011). Bilingualism and language planning shows how local identities and coexistence are negotiated from the street to the parliament to the arts and cinema as well as the ways in which global migrations and media intersect with local practices (Zontini 2010, Woolard 2011, Frekko 2011). And issues of human rights as immigrants, as citizens seeking autonomy and independence and in new "outraged" generations seeking a clear future continue to spill into the streets of Barcelona in marches and protests that claim the city as a changing crucible whether responding to globalization in 2003 or protesting local lack of opportunities for young people in 2011 (Juris 2008). Here, the text ends with Barcelona as a model for other cities in the ways that the city and its citizens face its own demanding questions (5000 words).

Bibliography: A preliminary bibliography is attached, with an emphasis for the moment on works available in English. Depending on editorial decisions it could be rearranged in sections or by chapter or expanded to better incorporate literature and film as well as sources for further reading.

\section{Preliminary Working Bibliography}

Abulafia, D. 2003. The Mediterranean in History. LA: J. Paul Getty Museum. Agustí, D. 2010. Breve Historia de Barcelona. Madrid: Silex Ediciones.

Aibar, E. and Wiebe E.B. 1997. "Constructing a City: The Cerdà Plan for the Extension of Barcelona". Science, Technology E Human Values, 22 (1). Winter 1997: 3-30.

Amelang, J.S. 1986. Honored citizens of Barcelona: patrician culture and class relations, 1490-1714. Princeton, N.J.* Princeton University Press.

- 1998. The flight of Icarus: artisan autobiography in early modern Europe. Stanford University Press.

—. 2007. “Comparing Cities: A Barcelona Model?” Urban History, 34: 173189.

—. 2008. "Gent de la Ribera" $i$ altres assaigs sobre la Barcelona moderna. Vic: Eumo.

Anderson, B. 2006. Under Three Flags: Anarchism and the Anti-Colonial Imagination. London: Verso. 
Arriaga, M. and Fúlvia, N. 2008. ¿Estan bojos Aquests Catalans? Barcelona: Angle Editorial.

Assemblea de Resistència al Fòrum. 2004. La otra cara del Forum de les Cultures, SA. Barcelona: Institut Català d'Antropologia.

BALfour, S. 1989. Dictatorship, workers, and the city: labour in Greater Barcelona since 1939. New York: Clarendon Press.

Batlle, C. et alii. 1982-2. La Societat Barcelonina a la baixa edat Mitjana. Barcelona: Departament d'història medieval, Universitat de Barcelona.

Bensch, S.P. 1995. Barcelona and its Rulers, 1096-1291. Cambridge.

Beltrán, J. and A. Sáiz. 2001. Els xinesos a Catalunya. Barcelona: Fundació Jaime Bofill.

Beltrán Moya, J.L. 1990. "Pobreza y marginación en la Barcelona de los siglos Xvi y xvir". Historia Social, No. 8 (Autumn): 101-121.

Blakeley, G. 2005. "Local governance and local democracy: The Barcelona model”, Local Government Studies, 31: 2,149.

Blanco, I. 2009. “Does a 'Barcelona Model' Really Exist? Periods, Territories and Actors in the Process of Urban Transformation". Local Government Studies, 35(3): 355 .

Boнigas, O. 1963 Barcelona entre el Pla Cerdà I el barraquisme. Barcelona:62.

- 1985 Reconstrucció de Barcelona. Barcelona: 62.

—. 1993. Gràcies i desgràcies culturals de Barcelona. Barcelona: Àrea de Cultura, Ajuntament de Barcelona.

-, P. Buchanan, and V. Magnago. 1991. Barcelona: City and Architecture 1980-1992. New York: Rizzoli.

Bollens, S. 2007. Cities, Nationalism and Democratization. London; New York: Routledge.

Bonnassie, P. 1975. La organización del trabajo en Barcelona a fines de siglo XV. Barcelona: Consejo Superior de Investigaciones Científicas.

Bou, E. 1999. "Churches and Streetcars in Barcelona: Ways to Modernity". Romance Quarterly. Washington: Fall Vol. 46, Iss. 4: 204-216.

Brandes, S. 2009. "Torophiles and Torophobes: The Politics of Bulls and Bullfights in Contemporary Spain”. Anthropological Quarterly, 82(3): 779795.

Braudel, F. 1966. La Méditerranée et le monde méditeranéen à l'époque de Philippe II. Paris: A. Colin. Translated as The Mediterranean and the 
Mediterranean World in the Age of Philip II. New York: Harper \& Row. 1972-3.

Busch, S. 2001. Medieval Mediterranean Ports: The Catalan and Tuscan Coasts, 100-1235. Leiden: Brill.

Busquets, J. 2005. Barcelona: the Urban Evolution of a Compact City. Cambridge: Harvard University Press (and Nicolodi Editore, Rovereto, Italy).

Cabana Vancells, F de. 1965. La Banca a Catalunya. Barcelona: 62.

Capmany, Antonio. [1779-92] 1963. Memorias bistóricas sobre la marina, comercio y artes de la antigua ciudad de Barcelona. Barcelona: Cámara Oficial de Comercio y Navegación.

Candel, F. 1964. Els altres Catalans. Barcelona 62.

- 1985. Els altres Catalans vint anys després. Barcelona: 62.

CApel, H. 2005. El modelo Barcelona: un examen crítico. Barcelona: Serbal.

- and P.-A. Linteau (dir.). 1998. Barcelone-Montreal: desarollo urbano comparado/developpement urbain compare. Barcelona: Publicacions de la Universitat de Barcelona.

Carrera Pujal, J. 1961. La economia de Cataluña en el siglo XIX. Barcelona: Bosch.

Carreras Verdaguer, C. 1992. Geografia Urbana de Barcelona: Espai Mediterrani, Temps Europeu. Barcelona: Oikos.

Castells, M. 1996. The Rise of the Network Society. Cambridge: Blackwell.

Catros, B.A. 2004. The Victors and the Vanquished: Christians and Muslims of Catalonia and Aragon, 1050-1300. Cambridge: Cambridge University Press.

Centre de Cultura Contemporània de Barcelona. 1998. La ciutat de la diferencia. Barcelona: CCCB.

- 1999. La ciutat sostenible. Barcelona: CCCB.

Cerdì, I. 1867. Teoría general de la urbanizació... Reprinted Barcelona: Cámara Oficial de Comercio y Navegación. 1968-71.

Chazan, A. 1992. Barcelona and Beyond:The Disputation of 1263 and its Aftermath. Berkeley: University of California Press.

Colectrvo IOE (W. Actis, C. Pereda, M.A. de Prada). 1994. Marroquins a Catalunya. Barcelona: Enciclopèdia Catalana. 
Colino, C. 2009. "Constitutional Change Without Constitutional Reform: Spanish Federalism and the Revision of Catalonia's Statute of Autonomy". Publius, 39(2): 262-289.

Congrès de Cultura Catalana. Manifest I documents. 1978. Barcelona.

Conversi, D. 1997. The Basques, Catalans and Spain: Alternative Routes to Nationalistic Mobilisation. Reno: University of Nevada Press.

Corteguera, L. 2002. For the Common Good: Popular Politics in Barcelona 1580-1640. Cornell University Press.

Costa Ruibal, O. 2002. L'Imaginari Imperial: El Noucentisme català i la politica internacional. Barcelona: Insituto Cambó.

Coulon, D. 2004. Barcelone et le grand commerce d'Orient a Moyen Âge: Un siècle de relations avec l'Égypte et la Syrie-Palestine (ca. 1330-ca. 1430). Madrid: Casa de Velázquez, Institut Europeu de la Mediterrània.

Davidson, R.A. 2006. "A Periphery with a View: Hotel Space and the Catalan Modern Experience”. Romance Quarterly. Washington: Summer 2006. Vol. 53, Iss. 3: 169-184.

-. 2009. Jazz Age Barcelona. Toronto: U Toronto Press.

Degen, M.M. 2008. Sensing cities: regenerating public life in Barcelona and Manchester. London; New York: Routledge.

Delgado, M. 2007. La ciudad mentirosa. Fraude y miseria del "Modelo Barcelona". Madrid: Catarata.

Delgado, L. and D. Lozano. 2007. Latinos en España. Madrid: Esfera de libros.

Di Castri, F. and H. Mooney, eds. 1973. Mediterranean Type Ecosystems: Origin and Structure. New York: Springer Verlag.

DiGiacomo, S. 1984. "The Politics of Indentity: Nationalism in Catalonia”. Unpublished Ph. D Dissertation. University of Massachusetts.

—. 2001. "Catalan is Everyone's Thing: Normalizing a Nation". Language, Ethnicity and the State, ed. C. O'Reilly. London: Palgrave, 56-77.

Domingo Clota, M. and M.R. Bonet. 1998. Barcelona $i$ els Moviments Socials. Barcelona: Fundació Jaume Bofill.

Dufourg, C.-E. 1966. L'Espagne Catalane et le Maghrib aux xime et XIVe Siècle: De la Bataille de las Navas de Tolosa (1212) à l'Avenement du Sultan Merinide Abou-l-Hasan. Bourdeaux: Université.

Duthel, H. 2011. FC Barcelona. IAC. 
Ealham, C. 2001. Anarchism and the City: Revolution and Counter-Revolution in Barcelona, 1898-1937. Oakland, Edinburgh and Baltimore: AK Press. New Ed.

Elliotr, J.H. 1963. The Revolt of the Catalans: A Study in the Decline of Spain, 1598-1640. Cambrifge: Cambridge University Press.

Epps, B. 2004. "Seeing the Dead” in S. Larson and E. Woods, eds. Visualizing Spanish Modernity. Oxford: Berg: 112-142.

Erickson, B. 2011. "Utopian virtues: Muslim neighbors, ritual sociality, and the politics of convivència". American Ethnologist, 38:1.

Eaude, M. 2010. Catalonia: A Cultural History. Oxford: Oxford University Press.

Fernández-Armesto, F. 1993. Barcelona. London: Sinclair-Stevenson.

Fontana, J. 1972. Bonaventura Carles Aribau I la industria cotonera catalana. Barcelona: Dalmau.

Frekko, S. 2009. “ «Normal» in Catalonia: Standard language, enregisterment and the imagination of a national public". Language in Society. Cambridge: 38(1): 71-94.

-. 2011."Containing Castilian in Catalan Talk Radio: Heteroglossia and the Projection of Monoglot Identities". Anthropological Quarterly. 84(1):65-87.

Furriol, E. 1990. "Una nova cultura productive a les empreses japoneses radicades a Catalunya". Món Laboral, 11 (segon semestre): 19-24.

Garbancho, P. 1995. La conquesta del verd. Barcelona: Ajuntament de Barcelona.

García, A. 1998. Un siglo decisivo. Barcelona y Cataluña, 1550-1640. Madrid: Alianza Editorial.

—.2005. Barcelona entre dues guerres. Economia i vida quotidiana, 1652-1714. Vic: Eumo.

- and M. Guàrdia. 1986. Espai i societat a la Barcelona pre-industrial. Barcelona: La Magrana.

Gdaniec, C. 2000. "Cultural industries, information technology and the regeneration of post-industrial urban landscapes. Poblenou in Barcelona: a virtual city?" GeoJournal. Vol. 50, Iss. 4: 379-387.

González, S. 2011. "Bilbao and Barcelona 'in Motion'. How Urban Regeneration 'Models' Travel and Mutate in the Global Flows of Policy Tourism". Urban Studies, 48: 7 (May): 1397. 
Grandas, M. 1988. L'exposicio internacional de Barcelona de 1929. Barcelona: Llibres de la Frontera.

Grau, R., ed. 1988. La Exposicion Universal de 1888. Barcelona: L'Avenç.

Grassilli, M. 2001 "Festes, ferias and hip-hop: images of multiculturalism in Barcelona" in R. KING, ed. The Mediterranean Passage. University of Liverpool Press, 66-94.

Guibernau, M. 1996. Nationalisms: The Nation-State and Nationalism in the $20^{\text {th }}$ century. Cambridge: Polity.

- 2004. Catalan Nationalism: Francoism, Transition, and Democracy. NY: Routledge.

Hansen, E. 1977. Rural Catalonia under the Franco Regime. Cambridge: Cambridge University Press.

Hargreaves, J. 2000. Freedom for Catalonia : Catalan Nationalism, Spanish identity, and the Barcelona Olympic Games. Cambridge: Cambridge University Press.

Harris, W.V. 2005. Rethinking the Mediterranean. Oxford: Oxford University Press.

Herzfeld, M. 2005. "Practical Mediterraneanism: Excuses for Everything from Epistemology to Eating" in Harris, W.V. 2005. Rethinking the Mediterranean. Oxford: Oxford University Press: 45-63.

Horden, P. and N. Purcell. 2000. The Corrupting Sea: a Study of Mediterranean History. Oxford: Oxford University Press.

Hughes, R. 1992 Barcelona. New York: Alfred Knopf.

Ingrosso, C. 2011. Barcelona: Architecture, City and Society 1975-2015. Milano: Skira.

Jacobson, S. 2009. Catalonia's advocates: lawyers, society, and politics in Barcelona, 1759-1900. Chapel Hill: University of North Carolina Press.

Jonas, A. and A. While. "Greening the entrepreneurial city?: looking for spaces of sustainability politics in the competitive city". In Krueger and Gibss, eds. The Sustainable Development Paradox. New York: Guilford: 123-160.

JuRIs, J.S. 2008 Networking futures: the movements against corporate globalization Durham, N.C.: Duke University Press.

Jutglar, A. 1972. Historia crítica de la burgesia a Catalunya. Barcelona: DOPESA. 
Kamen, H. 1993. The Phoenix and the Flame: Catalonia and the Counter Reformation. New Haven: Yale University Press.

-. 2003. Empire: How Spain Became a World Power. New York: Harper and Row.

- 2007.The Disinherited: The Exiles Who Created Spanish Culture. London: Allen Lane.

Kaplan, T. 1992. Red City, Blue Period. Berkeleyः University of California.

KIng, R., ed. 2001. The Mediterranean Passage. Liverpool: University of Liverpool.

—, L. Proudfoot and B. Smith, eds. 1997 The Mediterranean: Environment and Society. New York: John Wiley.

Keown, D., ed. 2011. A Companion to Catalan Culture. Rochester, NY: Tamesis.

Kinder, M. 1993. Blood Cinema: The Reconstruction of National Identity in Spain. Berkeley: University of California Press.

Klein, E. 2006. Jews, Christian society, and Royal Power in Medieval Barcelona. Ann Arbor: The University of Michigan Press.

Kosto, A.J. 2001. Making Agreements in Medieval Catalonia: Power, Order and the Written Word, 1000-1200. Cambridge: Cambridge University Press.

Kulikowski, M. 2004. Late Roman Spain and its Cities. Baltimore: The Johns Hopkins University Press.

Larson, S. and E. Woods, ed. 2005. Visualising Spanish Modernity. Oxford: Berg.

López, P. 1986. Un verano con mil julios y otras estaciones. Madrid: SigloXXI.

Lorés, J. 1983. La transició a Catalunya. Barcelona: Empúries.

McCully, M. 1978. Els Quatre Gats. Princeton: Art Museum.

McDonogh, G. 1986a. Good Families of Barcelona: A Social History of Power in the Industrial Era. Princeton: Princeton University Press.

—, ed. 1986b. Conflict in Catalonia. University Presses of Florida.

—. 1993."The Face Behind the Door: European integration, immigration and identity" in T. Wilson and M.E. Smith, eds. Anthropological Perspectives on European Economic Integration. T. Boulder Co: Westview: 143-160.

-. 1999. "Discourses of the City: Policy and Response in Post-Transitional Barcelona” in S. Low, ed. Theorizing the City: The New Urban Antbropology Reader. New Brunswick: Rutgers: 342-376. 
-. 2008. Iberian Worlds. New York: Routledge.

—. 2011. "Imagining the Mediterranean from Barcelona" in S. Duempelmann and D. Brantz, eds. Greening the City: Urban Landscapes in the Twentieth Century. Charlottesville: University of Virginia Press: 57-74.

—. 2012. "Learning from Barcelona: Discourse, Power and Practice in the Sustainable City" for special issue of City $\mathcal{E}$ Society on Urban Sustainability: Myth and Practice, ed. C. Ysenhour, M. Checker and G. McDonogh. Cambridge: Cambridge University Press.

- and Cindy Wong, "Beside Downtown: Chinatowns and Global Downtowns" in McDonogh, G. and M. Peterson, eds. Global Downtowns. Pennsylvania University Press: 273-296.

McNeill, D. 1999. Urban Change and the European Left. London: Routledge. McRoberts, K. 2001. Catalonia: Nation Building without a State. Oxford: Oxford University Press.

Mackay, D. 1985. Modern Architecture in Barcelona, 1854-1939. London: Anglo-Catalan Society.

Maragall, P. 1968. Refent Barcelona. Barcelona: 62.

Marfany, J. 1978. Aspectes del modernisme. Barcelona: Curial.

—. 2010. "Is it still helpful to talk about proto-industrialization? Some suggestions from a Catalan case study". The Economic History Review. Oxford: 63 (4): 942.

Marshall, T, 2000. "Urban planning and governance: Is there a Barcelona model?" International Planning Studies; Oct 5, 3: 299-319.

Martí, J. Barcelona Cultura. Barcelona: Institut de Cultura.

—, ed. 2004. Transforming Barcelona. London: Routledge.

Mascarell, F., ed. 1995. Els temps de la imaginació. Barcelona: Candidatura per a Barcelona 2001 .

Masjuan Bracons, E. 1992. Urbanismo y ecología en Cataluña. Móstoles: Madre Tierra.

Maspons Anglasell, F. 1907. Nostre dret familar. Barcelona: Alvar Verdaguer. Mauri, L. and L. Uría. 1988. La Gota Malaya: Pascual Maragall, la obstinación y el poder. Barcelona: Península.

MazA, G. 1999. "Inmigración, Marginación e Identidad en el Raval de Barcelona”. Unpublished Ph.D dissertation. Tarragona: Universitat Rovira i Virgili. 
Mendoza, E. 1986. La ciudad de los prodigios. Barcelona: Seix Barral.

Michonneau, S. 2001/2002. Barcelona: Memòria i Identitat. Monuments, commemoracions i mites. Vic: Eumo Editorial.

Molas Ribalta, P. 1975. Economia i societat al segle xviıI. Barcelona: Paraula Viva.

Monlau, P. 1848. Abajo las Murallas!!!! Barcelona.

Monnet, N. 2002. La formación del espacio público. Una mirada etnolólogica sobre el Casc Antic. Madrid: Catarata.

Monserdà de Macià, D. 1900. La familia Asparó. Barcelona: La Renaixença.

Moreras, J. 1991. Musulmanes en Barcelona. Barcelona: CIDOB.

Mutgé Vives, J. 2004. Política, urbanismo y vida ciudadana en la Barcelona del siglo XIV. Barcelona: CIEC.

NAdal, J. 1973. El fracaso de la revolución industrial en España. Barcelona: Ariel.

Nadal, J.M. 1965. Memories. Barcelona: Selecta.

Narotzky, V. 2007. La Barcelona del diseño. Barcelona: Santa \& Cole.

Nash, M.; R. Tello and N. Benach, eds. 2005. Inmigración, género y espacios urbanos. Barcelona: Bellaterra.

Nel-Lo, O. 2001. Ciutat de ciutats. Barcelona: Editorial Empúries.

- 2004. Las grandes ciudades españolas en el umbral del siglo XXI. Papers. Regió Metropolitana Barcelona 42: 11-62.

Obrador, P. and S. Carter. 2010. "Art, politics, memory: Tactical Tourism and the route of anarchism in Barcelona". Cultural Geographies, 17(4):525532.

Oliveras, L. 2011. Confesiones de un gangster de Barcelona. Barcelona: La Trama.

O'Reilly, K. 2000. The British on the Costa del Sol: Transnational Identities and Local Communities. London: Routledge.

Orwell, G. 1952. Homage to Catalonia. New York: Harcourt Brace Jovanovich.

Oyón, J.L. 2009. La Quiebra de la ciudad popular: espacio urbano, inmigración y anarquismo, 1914-1936. Barcelona de entreguerras, 1914-1936. Barcelona: Serbal.

Pareja, A., ed. 2008. Odio Barcelona. Barcelona: Melusina

Pi i Sunyer, N. 2006. L'exili manllevat. Barcelona: Proa.

Pi i Sunyer, O. 2006. "Pròleg," in C. Pi i Sunyer, Londres en Guerra, 19391942. Impressions d'un exiliat. Barcelona: Fundació Carles Pi i Sunyer, 9-36. 
—. 2008. "Crossing Borders, Reconfiguring Lives: A Catalan Exile Family in Wartime London" in S. Roseman and S. Parhust, eds. Recasting Culture and Space in Iberian Contexts. Albany: SUNY Press, 151-177.

Piera, M. 1998. Curial e Güelfa y las novelas de caballerías españolas. Madrid: Editorial Pliegos.

PLA, J. 1956. Obres completes. Barcelona: Selecta.

Preston, P. 1976, Spain in Crisis. Hassocks: The Harvester Press.

Prince of Wales Prize In Urban Design 1990: The Urban Public Spaces Of Barcelona 1981-1987. Cambridge: Harvard.

Prytherch, D.L. 2009. "New Euroregional Territories, Old Catalanist Dreams? Articulating Culture, Economy And Territory In The Mediterranean Arc". European Urban And Regional Studies, 16: 2 (April). Pujadas, X. and C. Santacana. 1991. L'altre olimpiada Barcelona 1936. Barcelona: Llibres de l'Index.

Resina, Joan Ramon. 2008. Barcelona's Vocation of Modernity: Rise and Decline of an Urban Image. Stanford: Stanford University Press.

Reilly, B.F. 1992. The Contest of Christian and Muslim Spain, 1031-1157. Oxford: Blackwell.

—. 1993. The Medieval Spains. Cambridge: Cambridge University Press.

ReIn, R. ed. 1999. Spain and the Mediterranean since 1898. London: Frank Cass. University of California Press.

-. 1996. Spain, Europe and the 'Spanish miracle' 1700-1900. Cambridge: University Press.

Riquer, B. de. 1977. Lliga regionalista. Barcelona: 62.

Ríos-Rojas, A. 2011. "Beyond Delinquent Citizenships: Immigrant Youth's (Re)Visions of Citizenship..." Harvard Educational Review; Spring 2011; 81, 1; Research Library IMH Proa.

Robinson, W.H.; Falgàs, J., and Belen, C., eds. (2007). Barcelona and Modernity: Picasso, Gaudi, Miró, Dalí. New Haven: Yale University Press / Cleveland Museum of Art.

Roca, J. 1997. Expansió urbana i planejament a Barcelona. Barcelona: Proa.

Roque, M.A. ed. 1989. Els Moviments Humans en el Mediterrani Occidental Generalitat de Catalunya. Barcelona: Institut Català d'Estudis Mediterranis. Ross, M. 2007. Cultural Contestation in Ethnic Conflict. Cambridge: Cambridge University Press. 
Rowe, P. 2006. Building Barcelona: A Second Renaixença. Barcelona: ACTAR. Rovira Virgili, A. 1912-14. Història dels moviments nacionalistes. Barcelona.

Rueda, S. 1995. Ecologia Urbana. Barcelona i la seva regió metropolitana com a referents. Barcelona: Beta.

Rueda, S. 2002. Barcelona, ciutat compacta $i$ complexa, una visió de futur mes sostenible. Barcelona: Ajuntament de Barcelona.

Rubió Tudurí, N.M. 2006. La patria llatina: de la Mediterrània a Amèrica. Abadia de Montserrat. Originally published 1946.

Sagarra de Castellarnau, Josep Maria de. 1977. Vida Privada. Barcelona: Aymá. First published 1932.

Sagarra y Trias, F. 1992. "Barcelone, la dynamique olympique et le project urbain” in J.L. Bonillo, A. Donzel and M. Fabre, eds. Métropoles portuaires en Europe. Editions Parenthèses: 23-34.

Sala, Tecla-M., ed. 2008. Barcelona 1900. Amsterdam: Van Gogh Museum/ Brussels Mercaterfond; Ithaca: Cornell University Press.

San Pedro, R. de 1952. Don Evaristo Arnús y Ferrer. Barcelona: Banco Atlãntico.

Schneidman, J.L. The Rise of the Aragonese-Catalan Empire, 1200-1350. New York: NYU Press.

Seidman, M. 1991. Workers against work: labor in Paris and Barcelona during the popular fronts. Berkeley: University of California Press.

Serra, E. 1988. Pagesos i senyors a la Catalunya del segle Xvir. Barcelona.

Smith, A. 2002. Red Barcelona: Social Protest and Labour Mobililzation in the $20^{\text {th }}$ Century. Routledge.

Sobreques i Callicó, J. 1992. Història de Barcelona. Barcelona.

Sokoloff, B. 1999. Barcelone ou comment refaire une ville. Montreal: Les Presses de l'Université de Montreal.

Strubell Trueta, M. 1981. Llengua i població a Barcelona. Barcelona: La Magrana.

Subirós, P. 1999. Estratègies Culturals I Renovació Urbana. Barcelona: Aula Barcelona.

—. 2011. "Don't Ask Me Where I'm From: Thoughts of Immigrants to Catalonia on Social Integration and Cultural Capital". International Journal of Urban and Regional Research. 35: 2 (March): 437. 
Tello, R.; N. Benach and M. Nash, eds. 2008. Intersticios. Contactos interculturales, género y dinámicas identitarias en Barcelona. Barcelona: Bellaterra.

Tello, R. and H. Quiroz, eds. 2009. Ciudad y diferencia. Barcelona: Bella Terra.

Terradas, I. 1979. Les colònies industrials. Barcelona: Laia.

Thomson, J.K.J. 1991. A Distinctive Industrialization: Cotton in Barcelona 1728-1832. New York: Cambridge University Press

Trallero, Manuel. 2004. Barcelona como mentira. Barcelona: Belacqua.

Tree, M. 2011. Barcelona, Catalonia. Catalonia Press.

Ucelay da Cal, E. 1995. "The Nationalisms of the Periphery: Culture and Politics in the Construction of National Identity" in H. Graham and J. Labanyi. Spanish Cultural Studies: An Introduction. Oxford: Oxford University Press, 32-39.

- 2003. El Imperialismo Catalán. Barcelona: Edhasa.

Vázquez Montalbán, M. 1992. Barcelonas, London: Verso.

Vicens Vives, J. 1963. Industrials i politics del segle XIX. Barcelona: Vicens Vives.

- 1957-9. Historia social y económica de Espana y América. Barcelona: Teide.

- 1970. Approaches to the History of Spain. Berkeley: University of California.

Vidal Folch, I. 2009. Barcelona Secret Museum. Barcelona: ACTAR.

VIlar, P. 1962. La Catalogne dans l'Espagne moderne. Paris: S.E.V.P.E. N.

Vives de Fabregas, E. 1945. Vida feminina barcelonesa de 1840 a 1920. Barcelona: Dalmau.

Woolard, K. 1989. Double Talk: Language and the Politics of Ethnicity in Catalonia. Stanford: Stanford University Press.

- 2011."Is there linguistic life after high school? Longitudinal changes in the bilingual repertoire in metropolitan Barcelona." Language in Society. Nov 2011. 40(5): 617-652.

Wynn, M. 1979. "Barcelona: Planning and Change 1854-1977". The Town Planning Review, Vol. 50, No. 2 (Apr.): 185-203.

Ynfante, J. 1974. Los negocios de Porcioles. Las sagradas familias de Barcelona Paris: Monopodio.

Zontini, E. 2010. Transnational Families, Migrtion and Gender: Moroccan and Filipino Women in Bologna and Barcelona. NY: Berghahn. 